\title{
The male bride: a story of Sexual Female-to-Male Transformation at marriage from the Hellenistic period, recorded by Phlegon of Tralles
}

\author{
Konstantina Barouti, ${ }^{1}$ Georgios K. Markantes, ${ }^{1}$ Anastasia K. Armeni, ${ }^{1}$ \\ Vasiliki Vasileiou, ${ }^{2}$ Neoklis A. Georgopoulos ${ }^{1}$
}

${ }^{1}$ Division of Reproductive Endocrinology, Department of Obstetrics and Gynecology, University of Patras Medical School, Patras, Greece, ${ }^{2} 1^{\text {st }}$ Department of Endocrinology, Diabetes Centre, "Alexandra" Hospital, Athens, Greece

\section{Dear Editor,}

Phlegon of Tralles was a Greek historian and writer, born in Tralles, a city of Lydia in Asia Minor. He was a freedman of the emperor Hadrian, who lived in the $2^{\text {nd }}$ century AD. Besides his magnum opus, "The Olympiads", among other writings of which only fragments have survived to date, he also produced a compilation of marvelous and abnormal natural or human phenomena presented as paradoxical stories in his collection called "Book of Marvels".

\section{A. Documentation of a "male bride" story, a case of female-to-male sexual transformation described by Phlegon of Tralles}

Among his narratives the following event is reported:

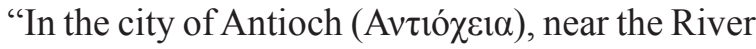

Key words: Ambiguous genitalia, Androgynism, Disorders of sexual development, $5 \alpha$ reductase deficiency, Heterosexual puberty, Phlegon, 17ßHSD deficiency

Address for correspondence:

Neoklis A. Georgopoulos: Department of Obstetrics and Gynecology, Division of Reproductive Endocrinology, University of Patras Medical School, Rio-26500, Greece; Tel:2610-999835, Fax:2610-993854, email: neoklisg@hol.gr Received: 17-01-2017, Accepted: 01-02-2017
Meander, lived another hermaphrodite at the time when the Lord of Athens was Antipater and the consuls of Rome were Marcus Vinicius and Titus Statilius Taurus (19 BC). Being a virgin aged 13 years old and of noble parents, she received a large number of marriage proposals, as she also was good-looking. On the day of her marriage, on her way out of her house she presented acute, excruciating internal pains and cramps. She was treated for abdominal pain by suitable practitioners, but after three days of various unsuccessful treatments none of the city's doctors could diagnose the cause responsible for her pain, which remained intolerable day and night. On the dawn of the fourth day her pain became much stronger and, suddenly, as she was screaming in agony, male genitals emerged and the girl turned into a man. Several years later she was presented to the Emperor Claudius; because of the portent, he had an altar built to Jupiter the Averter of Evil in the Capitolium". ${ }^{2}$

During Roman Imperial times, several Greek and Roman historians and philosophers, such as Titus Livius (59 BC - 17 AD), Pliny the Elder (23 - 79 AD) and Diodorus Siculus $\left(1^{\text {st }}\right.$ century $\left.\mathrm{BC}\right)$ included in their work cases of androgynous creatures, presenting them as faults of nature. ${ }^{3}$ By contrast, Phlegon incorporates such cases in his works as paradoxical stories. A "paradox" denoted the description of an unusual or grotesque event that aroused the intense curiosity of the audience and of readers. 
From a scientific point of view, is this case described by Phlegon pure fiction or could it be based on an actual event?

\section{B. Differential diagnosis of the male bride story}

Phlegon of Tralles described the story of a 13-year old girl who was sexually reassigned at the time of her marriage. The girl was most likely born with either ambiguous or female external genitalia. She was raised as a female and was preparing to marry a man when she experienced a sexual transformation. The writer explicitly reports the presence of male genitalia, appearing after three days of abdominal inflammation. As menarche is de facto excluded, it is reasonable to assume that the girl must have presented at least minimal breast development (thelarche) in order for her family to prepare her for marriage. Regarding the cause of the abdominal inflammation, in view of the available evidence, enlargement of the entrapped testes inside the inguinal canal due to the advent of puberty is the most likely explanation. Hence, we can assume that Phlegon in fact describes a case of a Disorder of Sexual Development (DSD) manifesting as heterosexual puberty.

Differential diagnosis of this case comprises virilizing tumors, gonadal dysgenesis, true hermaphroditism and male or female pseudohermaphroditism.

Considering the available evidence, the presence of a virilizing tumor can be easily excluded as these tumors are usually lethal if untreated due to their malignant origin. Gonadal dysgenesis is also unlikely as the manifestation of heterosexual puberty requires large amounts of androgens. Heterosexual puberty has never been reported in true hermaphrodites, while the undisputable presence of testes rules out female pseudohermaphroditism (46,XX DSD). ${ }^{4}$

Therefore, male pseudohermaphroditism (46,XY DSD) is the most likely cause in this case of female to- male transition. As heterosexual puberty has never been reported in Androgen Insensitivity Syndrome (AIS), a defect in steroidogenesis and in particular androgen synthesis is apparently the culprit. Of all the possible enzyme deficiencies in the steroidogenic pathway, only those of $17 \mathrm{~b}$ hydroxysteroid dehydrogenase (HSD17B3) or 5a reductase type 2 could lead to a phenotype characterized by ambiguous genitalia at birth and heterosexual puberty with spontaneous virilization.

5 a reductase converts testosterone to the far more potent dihydrotestosterone (DHT). 5a reductase type 2 , which is highly expressed throughout gestation in testicular, scrotal and phallic tissues, holds the key role with respect to male external genitalia formation. Its under-expression leads to decreased DHT levels and considerable genital ambiguity in the neonate, towards the female end of the spectrum. ${ }^{5}$

Unlike 5a reductase type 2 , type 1 is not expressed in utero; its expression increases with age and becomes clinically apparent in puberty. ${ }^{5}$ In 5 a reductase type 2 deficient males, entrance into puberty is characterized by an abrupt increase in DHT levels, as a result of type 1 isoenzyme action on accumulated testosterone. This manifests clinically as virilization and, possibly, heterosexual puberty.

$17 \mathrm{~b}$ hydroxysteroid dehydrogenase is the enzyme converting androstenedione to testosterone. Type 3 isoenzyme (HSD17B3) is expressed in the testes, while type 5 (HSD17B5) is mainly responsible for extragonadal production of testosterone. ${ }^{6}$ Moreover, transcription regulation of the enzyme isoforms is age-dependent: HSD17B3 expression decreases, while HSD17B5 expression increases with age, making their respective roles more important in utero for HSD17B3 and in puberty for HSD17B5. ${ }^{6}$ Hence, HSD17B3 deficiency may lead to ambiguous genitalia at birth, a feature which is reversed in adolescence by the normal action of HSD17B5.

As for the case under review, the key indicator for a conclusive diagnosis is the presence of breast development, which represents gynecomastia rather than thelarche. Gynecomastia is caused by an altered estrogen to testosterone ratio due to increased estrogen and/or decreased testosterone. As is known from physiology, gynecomastia is common in HSD17B3 deficient adolescents affecting up to $30 \%$ of patients, but is only rarely observed in 5a reductase type 2 deficiency. ${ }^{5,6}$

In conclusion, we may safely assume that the case described by Phlegon of Tralles was a 46,XY DSD-male pseudohermaphrodite presenting with heterosexual 
puberty. 5a reductase type 2 or HSD17B3 deficiency could account for this presentation, with the latter being more probable due to concurrent gynecomastia.

\section{REFERENCES}

1. McInerney J, 2010 "Phlegon of Tralles". Brill's New Jacoby. Editor in Chief: Ian Worthington (University of Missouri). Brill Online.

2. Hansen W, 1996 Phlegon of Tralles' Book of Marvels. University of Exeter Press, Exeter; pp, 38-39.

3. Armeni AK, Vasileiou V, Georgopoulos NA, 2013 When Genotype prevails: sexual female-to-male transforma- tion in Classical Antiquity, recorded by Gaius Plinius Secundus and Phlegon. Hormones (Athens) 13: 153-156.

4. Hughes IA, Houk C, Ahmed SF, Lee PA, 2006 LWPES1/ ESPE2 Consensus Group. Consensus statement on management of intersex disorders. Arch Dis Child 91: 554-562.

5. Mendonca BB, Batista RL, Domenice S, Costa EM, Arnhold IJ, Russell DW, et al, 2016 Steroid $5 \alpha$-reductase 2 deficiency. J Steroid Biochem Mol Biol 163: 206-211.

6. Mendonca BB, Gomes NL, Costa EM, Inacio M, Martin RM, Nishi MY, et al, 2017 46,XY disorder of sex development (DSD) due to 17 $\beta$-hydroxysteroid dehydrogenase type 3 deficiency. J Steroid Biochem Mol Biol 165: 79-85. 